\title{
Body Weight, Tick Burden (Boophilus microplus), Physiological Parameters and Reproductive Efficiency of Crossbred Zebu Cattle
}

\author{
By M. Garcia, W. Huanca and A. Chávez \\ Veterinary Institute for Tropical and High Altitude Research (IVITA), \\ University of San Marcos, Lima, Peru and Department of Clinical Chemistry, \\ Swedish University of Agricultural Siences, Uppsala.
}

\begin{abstract}
Garcia, M., W. Huanca and A. Chávez: Body weight, tick burden (Boophilus microplus), physiological parameters and reproductive efficiency of crossbred Zebu cattle. Acta vet. scand. 1989, 30, 347-353. - Body weight at calving, degree of tick load (Boophilus microplus), rectal temperature, respiratory frequency and heart rate were evaluated and correlated to reproductive efficiency in $63 \mathrm{~F}_{1}$ Brown Swiss $x$ Nellore milked animals reared in the tropical region of Peru. Cows were bred by free natural service, and first ovulation was estimated by progesterone measurements. The physiological parameters were registered at morning milking $(04.00$ to 06.00$)$ at an average air temperature of $22.4 \pm 0.9^{\circ} \mathrm{C}$.

The intervals from parturition to first ovulation and conception were significantly affected when the body weight at calving was lower than $400 \mathrm{~kg}(\mathrm{p}<0.01)$. The degree of tick burden, rectal temperature $\left(38.4 \pm 0.2^{\circ} \mathrm{C}, \overline{\mathrm{x}} \pm\right.$ s.e.), respiratory rate $(25.2 \pm 0.3$ breaths $/ \mathrm{min})$ and heart: rate $(66.7 \pm 0.4$ beats $/ \mathrm{min})$ were not related to post-partum reproductive efficiency. The average intervals from parturition to first ovulation and to conception were $56.3 \pm 55.5$ and $77.7 \pm 46.0$ days $\overline{\mathrm{X}} \pm$ s.d.), respectively. The fertility rate was $85.7 \%$. The results indicate the $F_{1}$ cross to be well adapted to the given environment. It remains to be determined whether higher levels of temperate blood can be used without an accompanying decrease in reproductive performande.
\end{abstract}

\section{Introduction}

In cattle the post-partum period and the time required for reestablishment of sexual functions is often quite variable, especially when animals are reared under harsh tropical environmental conditions. Through natural selection indigenous animals have become adapted to climatic stress, poor quality pastures, diseases and other related constraints. This seems, however, to have occurred at the expense of production and productivity. The introduction of exotic animals into the tropical regions for improvement of indigenous cattle by crossbreeding can be advantageous provided that adequate management, nutrition and veterinary services are available (Rendel 1972, Vaccaro 1973, Swensson et al. 1981, Garcia et al. 1989).

In a previous study, Bos taurus $\mathrm{x}$ Bos indicus crosses showed better reproductive performance, produced more milk and were considered by farmers to have a higher breeding value than purebred Bos indicus animals (Garcia \& Edqvist 1989a). The same study also revealed that nutritional status, measu- 
red in terms of body weight, showed a significant positive correlation with reproductive performance.

It is well established that Bos taurus animals are more susceptible to the cattle tick (Boophilus microplus) as well as to a variety of tropical diseases (Van der Walt \& Jansen 1968). The tick load of an animal is affected by breed, sex and lactational stage of the cow as well as by nutritional stress (Springell 1974). Different rates of infestation within hosts of the same genotype have been reported (Carr et al. 1974, Alexander et al. 1984, Ansell 1985). The degree of tick-resistence is highly heritable in Bos indicus cattle and their crosses and should be considered in selection programmes (Springell 1974, Vercoe \& Frisch 1986). Tick infestation affects appetite, body condition, blood composition and respiratory rate (Springell 1974) besides spreading tickborne diseases. The effect of tick infestation on post-partum reproductive performance is not well documented.

Various physiological parameters have been used in estimating tolerance to heat stress in cattle (Van der Walt \& Jansen 1968). In Cuba, Garcia et al. (1979) and Martinez Santiesteban et al. (1984) reported that rectal temperature and respiratory rate in Holstein $x$ Zebu crossbred calves and cows showed different responses to increases in air temperature depending on the genotype involved. However, milk production can be maintained provided that animals have the opportunity to loose heat at night (Johnston 1972). The purpose of this study was to evaluate certain adaptational parameters and relate them to the reproductive efficiency of the crossbred milked Zebu reared in the Peruvian Amazon environment.

\section{Material and methods}

Cows studied belonged to a large state-owned cattle farm located in the Amazon basin of Peru. The tropical climate of the area is characterized by an average annual temperature of $26.9^{\circ} \mathrm{C}$ and an average annual rainfall of $2,100 \mathrm{~mm}$, of which $78 \%$ falls during the rainy season, lasting from October until March.

Sixty-three $F_{1}$ Brown Swiss $x$ Nellore crossbred cows with parities from 1-8, ranging in age from 3 to 12 years, were studied from parturition until conception or 240 days post-partum. The calving period was from January to May, and all deliveries were free of perinatal diseases. Animals grazed native and improved grasses and were reared in a group of 100 lactating cows and 4 bulls of the same bred. Hand-milking was performed twice a day at which times animals also received concentrate ( 2 to $4 \mathrm{~kg}$ of a mixture of rice hull, brewer's grain, maize and fish meal).

Rectal temperature $\left({ }^{\circ} \mathrm{C}\right)$, respiratory rate (breaths/min), heart rate (beats $/ \mathrm{min}$ ) and the estimated degree of tick infestation were registered weekly during morning milkings (04.00 to 06.00$)$. The average air temperature at that time was $22.4 \pm 0.9^{\circ} \mathrm{C}$, while the average maximum day time temperature was $34.5 \pm 2.5^{\circ} \mathrm{C}$ ( $\overline{\mathrm{x}} \pm$ s.d. $)$. Heart rate was measured in the caudal artery. Adult Boophilus microplus were counted in a $20 \times 30 \mathrm{~cm}$ section of the perineal area. Animals were sprayed with ixodicides every 6-8 weeks. Cows were weighed within 2 weeks after parturition. Pregnancy diagnosis by rectal palpation was performed on a monthly basis. Milk samples for progesterone determination were collected from strippings at the time of the clinical examination. Samples were preserved by adding sodium azide and were kept at $+4^{\circ} \mathrm{C}$ until they were radioimmunoassayed using a commercial kit (FARMOS DIAGNOSTICA, Turku, Finland) employing ${ }^{125}$ I-labelled progesterone as tracer (Garcia \& Edqvist 1989b). The inter- 
assay coefficients of variation (CV) at progesterone concentrations of 4.1 and 44.3 nmol/1 progesterone was 18.2 and $7.5 \%$, respectively. The intra-assay CV was $<15.0 \%$ for progesterone concentrations ranging from 3.5 to $100 \mathrm{nmol} / \mathrm{l}$.

An ovulation was considered to have occurred if it was followed by elevated concentrations of progesterone $(>10 \mathrm{nmol} / 1$ in whole milk) in 2 consecutive weekly samplings. The degree of tick infestation was coded as $1:<8$ ticks, 2: 9-15 ticks, and 3: $>15$ ticks. The number of ticks registered during the fourth and fifth weeks after each of the first 3 spray applications post-partum was used for statistical analysis since the largest differences in tick infestation between animals were registered on these occasions. In the statistical analysis, the degree of tick infestation for each cow was taken as the average of the 6 counts.

The statistical analysis was performed by least squares analysis of variance according to the GLM procedure in the Statistical Analysis System ( $S A S$ 1985). The model to estimate the interval from calving to first ovulation and the interval from calving to conception included the effects of parity, age, body weight, tick infestation, rectal temperature, respiratory rate and heart rate. Furthermore, rectal temperature, respiratory rate and heart rate were used as dependent variables for evaluating the effects of age, parity and tick burden. Tick infestation was used as a dependent variable for determining the effects of age, parity and body weight.

\section{Results}

The overall mean and standard deviation for the variables studied are shown in Table 1 . The standard deviations for the intervals from parturition to first ovulation and conception were large. Nine cows (7 first calvers) did not conceive, and 4 cows among the
Table 1. Overall means for reproductive traits and body weight at calving in Brown Swiss $x$ Nellore cattle.

\begin{tabular}{lcr}
\hline Traits & No. of cows & Mean \pm s.d. \\
\hline $\begin{array}{l}\text { Parity } \\
\begin{array}{l}\text { Calving to first ovula- } \\
\text { tion interval (days) }\end{array}\end{array}$ & 63 & $4.1 \pm 2.4$ \\
$\begin{array}{l}\text { Calving to conception } \\
\text { interval (days) }\end{array}$ & 54 & $56.3 \pm 55.5$ \\
$\begin{array}{l}\mathrm{N}^{\circ} \text { of ovulations prior } \\
\text { to conception }\end{array}$ & 54 & $77.7 \pm 46.0$ \\
$\begin{array}{l}\text { Body weight at } \\
\text { calving }(\mathrm{kg})\end{array}$ & 63 & $406.7 \pm 73.6$ \\
\hline
\end{tabular}

first calvers had not ovulated by day 240 after parturition. Two multiparous cows had their first ovulations on days 29 and 33 postpartum and showed normal estrous cyclicity thereafter, but did not conceive. First ovulation occurred before 60 days post-partum in $63.3 \%$ of the animals, and $66.1 \%$ became pregnant before 100 days post-partum. The body weight range at calving was 223-545 $\mathrm{kg}$.

Table 2 shows the $\mathrm{F}$ values for some factors affecting the intervals from calving to first ovulation and conception. Body weight was the only significant source of variation for both traits $(\mathrm{p}<0.01)$. First calvers showed a tendency to have delayed first ovulations compared to older animals. The degree of tick infestation did not markedly affect the length of the intervals from parturition to first ovulation and to conception. However, cows that did not ovulate or conceive were not included in the analysis.

The average rectal temperature, respiratory rate and heart rate during the post-partum period was $38.4 \pm 0.2^{\circ} \mathrm{C}, 25.2 \pm 0.3$ breaths$/ \mathrm{min}$ and $66.7 \pm 0.4$ beats $/ \mathrm{min}(\overline{\mathrm{x}} \pm$ s.e. $)$, respectively. These physiological indicators did not influence the reproductive parameters measured here, and they were not affected by parity or age of the cow (Table 2). Furthermore, they did not show any significant variation between weeks post-partum 
Table 2. Least squares analysis of variance for the intervals from calving to first ovulation and to conception.

\begin{tabular}{|c|c|c|c|c|c|c|}
\hline \multirow[t]{2}{*}{ Source of variation } & \multicolumn{3}{|c|}{$\begin{array}{l}\text { Calving to first } \\
\text { ovulation interval }\end{array}$} & \multicolumn{3}{|c|}{$\begin{array}{c}\text { Calving to } \\
\text { conception interval }\end{array}$} \\
\hline & Df & MS & $\mathrm{F}$ & $\overline{\text { Df }}$ & MS & $\mathrm{F}$ \\
\hline Parity & 1 & 10,099 & 3.3 & 1 & 1,840 & 0.4 \\
\hline Age (days) & 1 & 5,812 & 1.9 & 1 & 667 & 0.1 \\
\hline Body weight (kg) & 1 & 33,853 & $11.0^{* *}$ & 1 & 32,293 & $6.9^{* *}$ \\
\hline Tick infestation & 1 & 3,002 & 1.0 & 1 & 0 & 0 \\
\hline Rectal temperature & 1 & 14 & 0 & 1 & 876 & 0.2 \\
\hline Respiratory rate & 1 & 272 & 0.1 & 1 & 1,486 & 0.3 \\
\hline Heart rate & 1 & 262 & 0.1 & 1 & 2,629 & 0.6 \\
\hline Error & 51 & 3,066 & & 48 & 4,697 & \\
\hline $\mathrm{R}^{2}$ & & & 0.36 & & & 0.25 \\
\hline
\end{tabular}

or between weeks following tick treatment. The degree of tick infestation did not influence rectal temperature, respiratory rate or heart rate. Furthermore, it was not influenced by parity, age or body weight of the cow.

The reproductive performance of lighter cows was lower than that for heavier animals, especially when considering the cal- ving to first ovulation interval $(\mathrm{p}<0.01)$. Only minor differences were observed between cows with body weights $>400 \mathrm{~kg}$ with respect to the length of intervals from calving to first ovulation and to conception (Table 3). The average body weight at calving of first calvers that did not conceive was $278 \pm 48 \mathrm{~kg}$ whereas for those that conceived it was $371 \pm 60(\mathrm{p}<0.01)$.

Table 3. Least squares means for effects of parity, body weight (kg) and degree of tick infestation (B. microplus) on the intervals from calving to first ovulation and to conception (days).

\begin{tabular}{|c|c|c|c|c|}
\hline & \multicolumn{4}{|c|}{ Intervals (days) from calving to } \\
\hline & \multicolumn{2}{|c|}{ First ovulation } & \multicolumn{2}{|c|}{ Conception } \\
\hline & $\mathrm{n}$ & LS mean \pm s.e. & $\mathrm{n}$ & LS mean \pm s.e. \\
\hline $\begin{array}{l}\text { By parity: } \\
-1 \text { st calvers } \\
-2 \text { nd to } 5 \text { th calvers } \\
->5 \text { calvers }\end{array}$ & $\begin{array}{l}15 \\
23 \\
21\end{array}$ & $\begin{array}{l}88.3 \pm 15.9^{\mathrm{a}} \\
55.1 \pm 12.0^{\mathrm{a}} \\
59.2 \pm 15.5^{\mathrm{a}}\end{array}$ & $\begin{array}{l}12 \\
22 \\
20\end{array}$ & $\begin{array}{l}86.2 \pm 16.2^{\mathrm{a}} \\
72.4 \pm 11.1^{\mathrm{a}} \\
97.1 \pm 14.2^{\mathrm{a}}\end{array}$ \\
\hline $\begin{array}{l}\text { By body weight: } \\
-<340 \mathrm{~kg} \\
-340 \text { to } 400 \mathrm{~kg} \\
-401 \text { to } 460 \mathrm{~kg} \\
->460 \mathrm{~kg}\end{array}$ & $\begin{array}{l}10 \\
14 \\
19 \\
16\end{array}$ & $\begin{array}{r}123.2 \pm 20.7^{\mathrm{a}} \\
75.8 \pm 13.8^{\mathrm{b}} \\
45.9 \pm 11.7^{\mathrm{c}} \\
25.2 \pm 14.0^{\mathrm{c}}\end{array}$ & $\begin{array}{r}7 \\
14 \\
18 \\
15\end{array}$ & $\begin{array}{c}119.6 \pm 19.6^{\mathrm{a}} \\
98.5 \pm 12.1^{\mathrm{ab}} \\
77.0 \pm 10.6^{\mathrm{bc}} \\
45.9 \pm 13.2^{\mathrm{c}}\end{array}$ \\
\hline $\begin{array}{l}\text { By tick infestation: } \\
-<1.7 \\
-1.7 \text { to } 2.4 \\
->2.4\end{array}$ & $\begin{array}{l}17 \\
26 \\
16\end{array}$ & $\begin{array}{l}60.8 \pm 12.7^{a} \\
66.4 \pm 10.3^{a} \\
75.4 \pm 12.5^{a}\end{array}$ & $\begin{array}{l}15 \\
24 \\
15\end{array}$ & $\begin{array}{l}79.2 \pm 12.4^{\mathrm{a}} \\
80.5 \pm 9.2^{\mathrm{a}} \\
96.0 \pm 12.4^{\mathrm{a}}\end{array}$ \\
\hline
\end{tabular}

a, b, c Means in a column within sections with different letters are significantly different $(p<0.01)$. 


\section{Discussion}

The dual purpose crossbred animal (Bos taurus $\mathrm{x}$ Bos indicus), used for both milk and beef production, has gained the interest of farmers in the Peruvian Amazon region during the last decade owing to promising production results (Garcia et al. 1989). In a previous study, the interval from parturition to first ovulation, determined by progesterone measurements, was about 120 days in crossbred milked Holstein x Nellore cows compared with 247 days in purebred suckled Nellore, both on the same nutritional regimen (Garcia \& Edqvist 1989a). The present study revealed an even lower figure (56 days) for the parturition to first ovulation interval for the crossbred milked Brown Swiss x Nellore. This lower figure is primarily due to the fact that cows which did not conceive during the experimental period were omitted from the statistical evaluation. If they had been followed long enough to obtain the date for first ovulation, it is probable that the figure for the calving to first ovulation interval would have been greater and close to that previously found (Garcia \& Edqvist 1989a). Nevertheless, in both experiments, the reproductive performance of the crosses was superior to that of similar genotypes on private neighbouring small farms (Garcia et al. 1989). The differences might be attributable to the calf-rearing strategies employed on small farms which allow calves to suckle for up to 6-11 months post-partum.

Several studies have pointed out the importance of adequate nutrition in the maintenance of post-partum reproductive functions (Peters 1984, Rutter \& Randel 1984, Tervit et al. 1977), energy intake being more important than protein intake in this regard (Richards et al. 1986, Wiltbank et al. 1964). In the present study, body weight at calving proved to be the only significant factor affecting reproductive performance. In con- trast to older and heavier animals, first calvers with a low body weight were not able to resume ovarian activity early after parturition and remained acyclic for periods longer than 8 months. In contrast to older cows, first calvers have to be on a nutritional plane allowing not only demands for maintenance and milk production to be met but also the demand for growth. This likely explains their relatively poor behaviour in terms of reproductive function. Nutritional status at calving has been reported to be more important for reproductive performance than the status during later stages of the post-partum period (Peters \& Riley 1982, Richards et al. 1986). This is in agreement with the present study where the animals with the lowest body weight at calving did not conceive. The lowering of body weights during the postpartum period has been reported to adversely affect reproduction in Nellore cows (Garcia \& Edqvist 1989a).

The variations in rectal temperature, respiratory rate and heart rate were minimal and unrelated to the number of weeks post-partum, tick burden or time of onset of postpartum sexual function. These data and the exceptionally high reproductive efficiency obtained in this study suggest that the crossbred animals were well adapted to the existing environment.

Although no direct relationship between tick burden and repoductive efficiency could be established, there seems to be a trend in the sense that the time from parturition to first ovulation and to conception increased with increasing tick load. It is possible that tick loads higher than those found here could affect reproductive efficiency negatively. The tick load of purebred Bos taurus animals reared in the region is much more severe than that found in the crossbred animals in this study (unpublished observation). The $F_{1}$ crossbred animals have obviously retained 
some of the tick resistance found in the Nellore animals. Moreover, by spraying against ticks at 6-8 week intervals, tick infestation levels were kept under control.

The crossbred animals seem to be well adapted to the prevailing environment in the sense that body temperature as well as respiratory and heart rates were unrelated to the reproductive parameters measured. Taken together the evidence indicates that the animals either did not generate excess metabolic heat or that generated metabolic heat was lost during the cooler part of the day. In conclusion, the reproductive performance of the crossbred animals studied was very satisfactory, with $63.3 \%$ of first ovulations within 60 days post-partum, $69.6 \%$ of the animals pregnant following their second post-partum ovulation and an overall fertility rate of $85.7 \%$. This resulted in a calving interval of less than 1 year for the multiparous cows. These figures compare well with data for animals reared in temperate parts of the world (Hunter 1984). Taken together the results of this study indicate the $F_{1}$ cross to be well adapted to the studied environment. It remains to be seen whether higher levels of temperate blood can be used while still maintaining adequate reproductive performance.

\section{Acknowledgements}

We thank Prof. L-E. Edqvist, Dep. of Clinical Chemistry, Swedish University of Agricultural Sciences for reviewing the manuscript. The study was supported by research grants from the International Foundation of Science (IFS), Stockholm, Sweden, and from the Joint FAO/IAEA Division, Section for Animal Production and Health, International Atomic Energy Agency, Vienna, Austria.

\section{References}

Alexander GI, Reason GK, Clark CH: The development of the Australian Friesian Sahiwal. A tickresistant dairy breed. Wld. Anim. Rev. 1984, 51, 27-34.
Ansell RH: Cattle breeding in the tropics. Wld. Anim. Rev. 1985, 54, 30-38.

Garcia L, Rodriguez ON, Planas MT: Estudio comparativo de la tolerancia al calor en los cruzamientos Holstein x Cebú $\left(F_{1}\right.$ y $\left.F_{2}\right)$ en clima cálido-húmedo. (Comparative study on heat tolerance in Holstein $\times$ Zebu crosses $\left(F_{1}\right.$ and $\left.F_{2}\right)$ in a hot-wet climate). Rvta. Cub. Cienc. Vet. 1979, $10,143-149$.

Garcia $M$, Huanca $W$, Echevarria $L$ : Reproductive performance of purebred and crossbred Zebu cattle under artificial insemination in the Amazon tropic. Anim. Prod. 1989, In press.

Garcia $M$, Edqvist $L-E$ : Effects of suckling, level of nutrition and crossbreeding on the reproductive performance of Zebu cattle. Submitted for publication (1989a).

Garcia M, Edqvist L-E: Progesterone determination and clinical examination of the reproductive organs in purebred and crossbred female Zebu cattle. Theriogenology $1989 \mathrm{~b}$, In press.

Carr WR, Macleod J, Woolf B, Spooner RL: A survey of the relationship of genetic markers, tickinfestation level and parasitic diseases in Zebu cattle in Zambia. Trop. Anim. Helth Prod. 1974, 6, 203-214.

Hunter RHF: Towards $100 \%$ fertilisation in inseminated cows, with particular reference to the site of sperm storage. Anim. Breed. Abstr. 1984, 52, 1-5.

Johnston JE: Housing and management problems in cattle production in humid tropics. Wld. Rev. Anim. Prod. 1972, 8, 64-69.

Martinez Santiesteban JA, Espinosa J, Morais M: Estudio de la tolerancia al calor de terneros $5 / 8$ Holstein x 3/4 Cebú y 3/4 Holstein x 1/4 Cebú, en dos épocas diferentes (seca y lluvia). (Studies on heat tolerance in 5/8 Holstein $\times 3 / 8$ Zebu and $3 / 4$ Holstein $\times 1 / 4$ Zebu calves in dry and wet seasons). Rvta. Cub. Cienc. Vet. 1984, 15, 191-199.

Peters AR: Reproductive activity of the cow in the post-partum period. I. Factors affecting the length of the post-partum acyclic period. Br. vet. J. 1984,. 140, 76-84.

Peters AR, Riley GM: Milk progesterone profiles and factors affecting post-partum ovarian activity in beef cows. Anim. Prod. 1982, 34, 145-153. 
Rendel J: Dairy cattle in hot climates. Wld. Rev. Anim. Prod. 1972, 8, 16-24.

Richards MW, Spitzer JC, Warner MB: Effect of varying levels of post-partum nutrition and body condition at calving on subsequent reproductive performance in beef cattle. J. Anim. Sci. 1986, 62, 300-306.

Rutter LM, Randel RD: Post-partum nutrient intake and body condition: effect on pituitary function and onset of estrus in beef cattle. J. Anim. Sci. 1984, 58, 265-274.

SAS Institute Inc. SAS User's Guide: Statistics, Version 5 Edition. SAS Institute Inc. Cary, NC: 1985.

Springell PH: The cattle tick in relation to animal production in Australia. Wld. Anim. Rev. 1974, 10, 19-23.

Swensson C, Schaar J, Brännäng E, Meskel LB: Breeding activities of the Ethio-Swedish integrated rural development project. Part III: Reproductive performance of Zebu and crossbred cattle. Wld. Anim. Rev. 1981, 38, 31-36.

Tervit HR, Smith JF, Kaltenbach CC: Post-partum anoestrus in beef cattle: A review. Proc. N. Zeal. Soc. Anim. Prod. 1977, 37, 109-119.

Vaccaro L: Some aspects of the performance of purebred and crossbred dairy cattle in the tropics. Part I. Reproductive efficiency in females. Anim. Breed. Abstr. 1973, 41, 571-589.

Van der Walt K, Jansen BC: Adaptation to stress and disease. In: Hafez, E. S. E. Adaptation of Domestic Animals. Lea \& Febiger, Philadelphia, 1968, pp. 215-230.

Vercoe $J E$, Frisch JE: Utilizing genotype $\mathrm{x}$ environment interactions for improving the productivity of cattle in the tropics. In: Nuclear and Related Techniques in Animal production and Health.
International Atomic Energy Agency, Vienna, 1986, pp. 57-67.

Wiltbank $J N$, Rowden WW, Ingalls JE, Zimmerman $D R$ : Influence of post-partum energy level on reproductive performance of Hereford cows restricted in energy intake prior to calving. J. Anim. Sci. 1964, 23, 1049-1053.

\section{Sammenfattning}

Kroppsvikt, fästinginfestation (Boophilus microplus), fysiologiska parametrar och reproduktionsförmåga hos Zebukorsningsdjur.

I försöket ingick 63 stycken $F_{1}$-mjölkdjur (Brown Swiss x Nellore) hemmahörande i den tropiska delen av Peru. Kroppsvikt vid kalvning, grad av fästinginfestation (Boophilus microplus), rektaltemperatur, andnings- och hjärtfrekvens bestämdes och korrelerades till djurens reproduktionsförmåga. Korna betäcktes genom naturlig betäckning. Tidpunkten för första ovulation efter förlossningen bestämdes genom progesteroanalys av mjölk. De fysiologiska parametrarna registrerades vid tidpunkten för morgonmjölkningen (04.00-06.00). Medeltemperaturen vid denna tidpunkt var $22.4 \pm 0.9^{\circ} \mathrm{C}$. Kor som vägde mindre än $400 \mathrm{~kg}$ vid kalvningen hade en signifikant längre tid från förlossning till första ovulation $(\mathrm{p}<0.01)$. Graden av fästinginfestation, rektaltemperatur $\left(38.4 \pm 0.2^{\circ} \mathrm{C}, \mathrm{x} \pm\right.$ s.e. $)$, andnings- $(25.2$ \pm 0.3 andetag/min) och hjärtfrekvens $(66.7 \pm 0.4$ slag/min) påverkade inte reproduktionsförloppet. Medelintervallet från förlossning till första ovulation och till konception var $56.3 \pm 55.5$ respektive $77.7 \pm 46.0$ dagar. Fertilitetsprocenten var $85.7 \%$. Resultaten antyder att F1-korsningsdjuren är väl anpassade till sina levnadsbetingelser. Det återstår att visa om detta också gäller fär djur med högre andelar tempererat (Bos taurus) blod.

(Accepted November 28, 1988).

Reprints may be requested from: Dr. M. Garcia, IVITA, Apartado 4270, Lima, Peru. 
